\title{
Regulatory Governance Regimes and Interregionalism: Exploring the Dynamics of EU-Mercosur Negotiations
}

This paper examines the impact of interregionalism on regulatory governance. Specifically, it analyses an underexplored aspect of the negotiation process for an interregional agreement between the European Union (EU) and the Common Market of the South (Mercosur): To what extent and how has this given rise to particular forms of regulatory governance in Mercosur?

The paper empirically explores the trade and cooperation agendas involved in trade facilitation and education, and argues that the long negotiation process between the EU and Mercosur has affected the ways in which different forms of regulatory governance are expressed. Still, these show variation across policy issues. Both the type of norm promoted and the capacity-building mechanisms envisaged create a particular ideational and material context, all of which affects the actor constellation and leads in turn to different regulatory governance regimes, yet within the same interregional negotiation process.

Keywords: Interregionalism, European Union, Mercosur, trade facilitation, education, regulatory regimes

Este artículo examina el impacto del interregionalismo sobre la gobernanza reguladora. Específicamente, analiza un aspecto inexplorado del proceso de negociación del acuerdo interregional entre la Unión Europea (UE) y el Mercado Común del Sur (Mercosur): ¿En qué medida y de qué manera dicho proceso ha dado lugar a formas particulares de gobernanza reguladora en el Mercosur?

El trabajo explora empíricamente las agendas comerciales y de cooperación implicadas en el área de facilitación del comercio y educación, y argumenta que el largo proceso de negociación entre la Unión Europea (UE) y el Mercado Común del Sur (Mercosur) ha afectado las formas en que las diferentes formas de gobernanza reguladora se expresan. De todas maneras, éstas muestran variación entre las áreas de política. Tanto el tipo de norma promovida como los 
mecanismos establecidos para el desarrollo de capacidades dan lugar a un particular contexto ideacional y material, todo lo cual afecta la constelación de actores y conduce a su vez a diferentes regímenes de gobernanza reguladora, aún dentro del mismo proceso interregional de negociación.

Palabras clave: Interregionalismo, Unión Europea, Mercosur, facilitación del comercio, educación, regímenes reguladores 


\section{Introduction}

Transnational and global regulation is a significant feature of international politics today (Jordana and Levi-Faur 2004). An inherently uneven process, regulation takes place at different institutional levels (Duina 2006).

From a regional perspective, incorporation into regional groupings has been portrayed as promoting regional modes of regulation. In this respect, the expansion and diffusion of regulation across the European Union (EU) has been studied extensively in terms of how the regional organization affects domestic policies, institutions and political processes of both member states and accession candidates (Börzel and Risse 2007; Bruszt and McDermott 2012; Featherstone and Radaelli 2003; Treib 2008). Additionally, as the EU engaged in interregionalism, the bloc has attempted to establish new regulatory frameworks in the Global South (Grugel 2004).

Certainly, the European bloc has been the most vocal advocate of deepening trade agendas as a way of promoting both its liberalization and regulatory governance models since the end of the Uruguay Round and the creation of the World Trade Organization (WTO). However, as the Doha Development Round faded, the EU turned to other relevant scenarios for further promoting these regulatory agendas (Young and Peterson 2006; EC 2004). The negotiation process between the EU and Mercosur ${ }^{1}$ has not been an exception to this normative aspiration. The agreement focuses not simply on the expansion of trade, but also addresses the obstacles posed by national rules on economic flows by requiring newly harmonized regulatory frameworks in a diverse set of policy areas, pushing thus into deep integration.

Portrayed as the process of dialogue and relations between two regional organizations, interregionalism became a phenomenon of increasing relevance in international political economy starting in the 1990s and as corollary of the new or open regionalism (Rüland 2010; Doctor 2007). The literature has analysed the EU-Mercosur process in an extensive manner as it offered an eloquent example of EU-driven interregionalism. Simply put, interregionalism is portrayed as playing a fundamental

\footnotetext{
${ }^{1}$ Negotiations with the EU include Argentina, Brazil, Paraguay and Uruguay; who have been members of MERCOSUR since 1991. Though also a member, Venezuela is not part of this negotiation because it only joined the bloc in 2012, years after the process formally began, and is still in the process of adapting to Mercosur's rules and regulations.
} 
role in the development of regionalism as it promotes norm and capacity building through the engagement of two regions of qualitatively asymmetric profile (Doidge 2007) as in the case of the EU and Mercosur. However, it is less clear how and to what extent interregionalism impacts on regional integration overseas, which role the EU plays in this process (Doctor 2015). It is also remains underexplored whether this process of 'regionalism through interregionalism' (Hänggi 2003) leads to an unequivocal impact of the external other on all policy areas. More specifically, to my knowledge studies have not focused on the ways in which EU-Mercosur negotiations have made an impact on regional regulatory governance.

Given the above gaps in the literature and the recent agreement between the EU and Mercosur to move forward with these longstanding negotiations, this article makes an original contribution by examining the following research question: How, and to what extent, has the interregional process between the EU and Mercosur promoted regulatory governance regimes at the regional tier of governance in the South?

Empirically, the paper analyses and comparatively assesses the EU-Mercosur negotiation across two policy sectors: trade facilitation and education. Do these agendas trigger different forms of regulatory governance? Which elements account for the observed differences and similarities? Based on a "policy creates politics" argument (Lowi 1964), this study explores the factors facilitating or constraining particular forms of regulatory governance in these policy areas at the (inter) regional level. It argues that the agendas under negotiation vary in terms of the norms and capacity-building mechanisms promoted, which in turn can shape the prominence of distinct actors and networks, hence leading to particular forms of regulatory governance.

The article develops these arguments in five sections. Section 2 discusses the role of interregionalism in the promotion and support of regulatory regimes at the regional tier of governance, whereas section 3 presents a framework for the subsequent empirical analysis. Drawing on official documents and statements, as well as interview materials, section 4 explores the dynamics between the norms, capacity-building mechanisms deployed and the actor constellation across trade facilitation and education. After presenting a comparative assessment in section five, the article concludes by drawing out the implications for understanding the significance of interregionalism for the new phase of EU-Mercosur negotiations and for regional regulatory governance in general. 


\section{Regulatory governance: From the global to the regional and interregional levels}

Since the 1980s, the world has been going through a process of globalization that, rather than precluding the disappearance of rules, has ran parallel to the widening and deepening of regulation. A new order of regulatory capitalism (Levi-Faur and Jordana 2005) has thus been in the making as shown by the intense diffusion of regulatory activities, the creation of new regulatory institutions, technologies and instruments, together with the increasing scope and breadth of regulatory norms and standards. Regulation increasingly entails the fragmentation of power and control between state and non-state actors, on the hand, and the conformation and articulation of networks and alliances among them on the other (Djelic and Sahlin-Andersson 2006). Additionally, it also proceeds at different institutional levels of governance.

In the interests of economic competitiveness and growth, states have surrendered particular areas of their regulatory authority to transnational organizations and regimes (Lipschutz and Fogel 2002). Regional organizations have also been portrayed as giving way to regional models of regulation. Here, the EU turns out to be a paradigmatic case: as the single market developed, a distinctive European model of regulation evolved, combining national and supranational rule. In turn, this led to the growth and consolidation of the so-called EU regulatory state that promotes governance through rules and regulations (Majone 1994; McGowan and Wallace 1996; Lodge 2008). As the notion became increasingly contested, scholars promoted a more nuanced understanding of the EU as a regulatory state. Moving beyond statist approaches, analysis have explored the role of networks of national and EU-level regulators and regulatory agencies (Cohen and Thatcher 2008; Eberlein and Grande 2005), and looked into the various regulatory modes covering different policy areas (Knill and Lenshow 2004).

Similar analyses are still in short supply regarding regional processes in the developing world. Only recently, studies have acknowledged the emergence of new patterns of regulatory regionalism as original projects of new or open regionalism petered out (Söderbaum and Sbragia 2010; Phillips 2001). Though still rudimentary especially when compared to the already institutionalized and supranational regulatory governance mechanisms in the EU, new types of regulatory governance have been taking shape in the South (Jayasuriya 2008). From a domestic perspective, analysis relate these regional regulatory developments to the movement towards new forms of regulatory statehood (Hameiri and Jayasuriya 2011; Jayasuriya 2009) through the 
delegation towards independent regulatory agencies (Bianculli 2013; Dubash and Morgan 2012).

However, and despite the strong revitalization of regions and the deepening of intraregional relations, how interregionalism can contribute to the articulation of regulatory regimes in the Global South has remained underexplored.

Taken as "region-to-region relations", interregionalism has imbued EU's external policies since the 1990s (Söderbaum and Van Langehove 2005). Whereas the EU has maintained relations with most world regions, including Africa, Asia, and Latin America, interregionalism has been particularly strong within EU's strategy towards the latter. Within Latin America, the most developed relationship has been with Mercosur (Santander 2005). The EU-Mercosur partnership stood out as one of the most developed cases of interregionalism that exists until very recently when the EU shifted towards strategic partnerships, as in the case of the one established with Brazil in 2007.

However, interregionalism has not gone uncontested, and debate on EU-Latin American relations has revolved around the limited capacity of follow-up and implementation of the agreements reached and the difficulties to promote or advance a common position of the participants in relevant international fora (Maihold 2010). Implicitly, this suggests that the 'globally active' type of interregionalism taken as an 'expression of interregional cooperation on the global stage' (Doidge 2007: 242-243) has remained mostly absent, whereas capacity building has been a more significant factor.

In fact, interregionalism proved to be a useful tool to push for regional integration worldwide, including Latin America. The EU's interregional strategy clearly reflected its own commitment to market-building and economic liberalization, on the one hand, and to the embedding of market economies in a framework marked by the support of political dialogue, cooperation and democracy, civil society participation and social inclusion, on the other. Furthermore, to the extent that the policy and institutional regulatory framework endorsed by the EU was based on its own experience, through these economic, political and cooperation agendas, the bloc actively promoted its particular institutional model of regional integration (De Lombaerde and Schulz 2009; Farrell 2009). 
Mercosur is a case in point. The EU supported the creation of the customs union (Sanchez Bajo 2005) by market building (Lenz 2012) and was an active agent in the design and constitution of the regional parliament (Dri 2010) and of the Economic and Social Consultative Forum (Grugel 2004). The EU's technical support and the creation of epistemic networks supported Mercosur's institutionalization (Botto 2009) and were also relevant in the transmission of democratic norms and social citizenship (Grugel 2007). In sum, scholars have acknowledged and assessed the EU's continuous political and economic efforts to promote its own model in the region (Briceño-Ruiz and Puntigliano Rivarola 2009). Yet one question remains unanswered: to what extent and how has this interregional process given rise to particular forms of regulatory regimes in Mercosur?

This is especially relevant in the case of Latin America, where regional integration has remained, until recently, "asymmetric": countries have largely pursued integration through "negative regulation," but this has not been matched by "positive regulation" (Holman 2004). Furthermore, North-South interregionalism involves rule makers and rule takers. As a regulatory state, "the EU is a generator of standards to which other actors may converge" (Damro 2012, 687). Moreover, because of the limited capacity of rule takers - namely, developing countries - they are expected to comply with the rules and standards set by the former (Bruszt and McDermott 2012). However, integration can leave the "regime takers" marginalized or force the "regime makers" to adjust their goals and the way they use their power (Ruggie 1982). In all, fully understanding interregionalism and its impact on regulatory governance regimes in the South requires shedding light on actor constellations and material and ideational factors.

\section{Regional regulatory governance: What role for interregionalism?}

Whereas the precise definition of the relation between regulation and trade can sometimes be blurred (Woll and Artigas 2007), I understand regulation as formal and informal rules promoted by constellations of multiple (state and non-state) actors across different levels: national, regional and interregional. Regulation hence proceeds not only by means of legal sanctions and coercive powers but also through softer mechanisms. 
Indeed, the creation and embedding of social norms, shared standards and voluntary schemes by states, corporations and civil society may well be more effective.

Based on these insights, the paper empirically explores the negotiation process between the EU and Mercosur, to see whether and how interregional negotiations promote the emergence of particular regulatory governance regimes, taken as regulatory spaces encompassing rules, norms and institutional procedures about which actors' expectations converge in a given policy area. Focus is placed on the institutional setting promoted by the negotiation of regulatory commitments across policy areas, and which refers to the nature of the norms promoted and the capacity-building mechanisms envisaged.

First, the norms promoted can vary between regional and international norms on the one hand, and between external-regional norms as when the norms encouraged by another regional bloc prevail over locally inspired norms, namely, domestic-regional ones. Second, capacity-building measures include the type and amount of resources provided; the particular actors targeted and the cooperative requirements involved. Resources can be financial, informational or organizational.

Whereas the specific type of assistance and the amount of resources deployed are relevant, the second dimension - the type and number of actors addressed by these various mechanisms - is, in fact, a more significant factor when depicting the institutional setting. These mechanisms can range from those having an exclusive focus on state actors, privileging them over societal representatives, to more inclusive patterns addressing both the state and society. The latter, however, does not exclude the fact that particular civil society groups might be privileged over others. Furthermore, not only state and non-state actors vary in their capacities and resources to shape the definition of regulatory rules, but variation is also especially evident across business and civil society. Therefore, disentangling how the capacity-building strategies work in terms of the actors addressed is crucial: to the extent that they address different relevant state and societal actors, they provide incentives and a variety of resources, all of which are expected to improve regulatory governance. Finally, the cooperative requirement refers to the extent to which these capacity-building mechanisms require cooperation at the regional or international levels.

This framework is applied to the comparative assessment of two policy issues: trade facilitation and education. Both services liberalization in education and trade 
facilitation entail positive and negative integration policies (Scharpf 1999b). On the one hand, trade facilitation and the liberalization of educational services involve shallow or negative integration policies - namely, the removal of border barriers to trade or agreements on rules that should be prevented - to allow market creation. Still, these issues also demand deep or positive integration policies: they require the harmonization and coordination of norms and standards, or mutual recognition of each other's regulatory processes and standards.

More specifically, trade facilitation measures move inside or behind the border of domestic policies and governance structures, by including, for example, the agreement on standards of procedure and monitor agency conduct (Chauffour and Maur 2010). In the case of education, the negotiation of regulatory commitments in this area directly affects the role of the state in the provision of public services, as they entail, among others, the regulation of domestic services production that discriminate against foreigners, or the harmonization of accreditation processes to allow for the circulation of teachers and students. Whereas these are "fundamental services for the effective implementation of a series of social rights" (Verger 2008, 19), trade liberalization in education may introduce limitations on state regulation, expand private sector education and even affect educational quality. These might hence find high resistance because of ideological and normative differences among states, but also due to their different level of economic development and institutional arrangements (Scharpf 1999a).

In all, the negotiation of these agendas reaches deep into domestic governance arrangements. Still, while education is conceived as a public good, and trade liberalization in this area challenges traditional regulatory and institutional governance frameworks guiding the provision of education, trade facilitation is catalogued as the more technical area. Regulation works differently in these sectors as they stand for different representations of risk and hence entail diverse patterns of cooperation and conflict. Additionally, given the relevant variance in terms of the distribution of anticipated costs and benefits, they have a different impact on the incentive structure, and hence mobilization patterns of different actors (Lowi 1964; Wilson 1980).

Building on these insights, this paper analyzes to what extent the interregional negotiation process between the EU and the Mercosur leads to the articulation of new forms of regulatory governance in the Southern bloc. However, and given the variation observed across economic and social regulation, my expectation is that the negotiation 
of regulatory commitments in trade facilitation and education will trigger different policy dynamics, leading in turn to diverse regulatory governance regimes within the interregional process. In other words, I expect to find different combinations of programs, actors and networks underlying the shaping of regulatory regimes in these two areas in Mercosur. The underlying assumption is that different trade agendas elicit particular policy dynamics underpinned by strategic actor constellations, whose nature, roles and network configurations will be determined by the institutional setting of the negotiation process, namely the specific norms and capacity-building mechanisms devised.

The narrative builds on the analysis of interview material, secondary literature and relevant written documents including the Regional Strategy Papers (RSP) in which the European Commission (EC) identifies the objective and guidelines for EU policy towards Mercosur, with a focus on the 2000s. These regional strategies are complemented by the Regional Indicative Programmes (RIP) describing the specific sector measures, periods and planned financial engagement and expenses.

\section{Interregional negotiations and Mercosur (emerging) regional regulatory regimes}

The EU-Mercosur relationship is based on the Interregional Framework for Cooperation Agreement (EMFICA) signed in 1995 to promote an Interregional Association Agreement founded on three pillars: trade liberalization, political dialogue and cooperation. ${ }^{2}$ After long years of intense and legally driven relations across the Atlantic, trade negotiations were launched in 1999. Sixteen years later and after nine negotiation rounds (the last one in October 2012), concluding a final agreement still seems elusive. During the EU-Mercosur Ministerial Meeting that took place in June 2015, in the margins of the recently created EU-CELAC (Community of Latin American and Caribbean States) Summit, both parties exchanged general information on their respective market access offers. Just one month later, Mercosur members committed to

\footnotetext{
${ }^{2}$ The Framework was the next step from the 1992 Inter-Institutional Cooperation Agreement, the Joint Declaration of 22 December 1994, which already established the institutionalization of political dialogue and economic negotiations as the two pillars of the relationship, and the Declaration on Political Dialogue of 15 September 1995.
} 
negotiate jointly with the EU as Brazil, Paraguay and Uruguay declined unilateralism and demanded Argentina to remove domestic barriers to strengthen thus intraregional trade flows (La Nación 2015). In April 2016, the EU and Mercosur agreed to exchange fresh market access offers in the second week of May. In all, renewed political support by Mercosur members seems to be paving the way for the association agreement with the EU.

In 2004, negotiations had been abandoned because of differences over the trade agenda, mainly in manufactured goods, services and agriculture, but were re-launched four years later at the EU-Latin America and the Caribbean (EU-LAC) Summit (Madrid, May 2010). ${ }^{3}$ Nevertheless, the suspension of trade negotiations did not bring a loss of EU interest in the region. Relations continued through ministerial and informal technical meetings intended to deepen the agenda on political dialogue and cooperation (Botto and Bianculli 2011). Hence, even if trade negotiations followed a stop and go pattern, the EU relied on a fundamental instrument to facilitate and thus maintain the process: financial cooperation and technical assistance as depicted in the various RSP.

The interregional process envisages a comprehensive trade agreement, which covers not only trade in industrial and agricultural goods, but also services, improvement of rules on government procurement, intellectual property rights, customs and trade facilitation, and technical barriers to trade. Clearly, this reflects the EU's "new trade and development agenda" and its growing emphasis on regulatory issues, capacity-building and aid for trade (Faber and Orbie 2008). Within this context, the agreement with Chile (2002) was already portrayed in the early 2000s as the most comprehensive example of the EU's trade policy towards the South and as the bloc's "ideal framework" for its bilateral trade relations (Lamy 2002). The negotiation process with Mercosur was intended to follow similar steps: "the negotiations will cover the whole range of sectors, because Europe will come with its own interests, such as industry, services, public procurement, and intellectual property" (Lamy 2002). Furthermore, the interregional arena would explore "complementary negotiation methods to bring more ambitious results" (Mandelson 2005).

Even if the negotiation has not led to the signing of a single and comprehensive agreement containing clear commitments, these long years of negotiations have

\footnotetext{
${ }^{3}$ Similar differences explain the delay of negotiations since 2010 relaunch (van Loon 2015).
} 
provided an institutional setting in which interactions occur, promoting communication, socialization, and persuasion. Participation in trade negotiations has promoted a learning-by-doing process (Bianculli forthcoming). This process has opened a space where different state and societal actors, operating at the national and (inter) regional levels, promote, negotiate and contest not only trade liberalization rules but also regulatory frameworks reaching into social and political domains. Furthermore, it provides financial, informational and organizational resources to specific actors in an attempt to encourage capacity-building (Börzel, Pamuk et al. 2008). Portrayed as "an enabling instrument," capacity building can allow governments, business and civil society to accept and adopt specific policy ideas and institutions. This paper delineates how certain combinations of norms and capacity-building mechanisms devised within the EU-Mercosur interregional negotiations promote or restrain specific "strategic constellations as they are defined by the institutional setting within which interactions take place" (Scharpf 1999a, 70) shaping, in turn, the particular regulatory governance regimes at Mercosur level.

\section{Trade facilitation within the EU-Mercosur process}

\section{Norms and capacity-building mechanisms}

The 2002-2006 RSP links cooperation to support for the negotiation process and highlights the creation of the Mercosur common market. In fact, and given the early stage of both Mercosur's customs union and common market, which suffered from relevant internal barriers, interregional cooperation was to deepen the institutionalization and enforcement of common rules and standards, while removing non-tariff barriers impeding trade among partners, as in the case of customs duties. This was fundamental to deepening the integration process and facilitating trade among member countries. In turn, the implementation of facilitation measures upholding interdependence between the two regions was a prerequisite for the conclusion of negotiations and the future sustainability of the association agreement.

Organized into three main areas, cooperation in trade facilitation was incorporated under the priority "Institutionalization of Mercosur," whose final objective was "the possible creation of Mercosur regulatory bodies" (EC 2002a, 29-30). Capacitybuilding mechanisms included both financial and informational assistance. In financial 
terms, $26 \%$ of the total funding was devoted to institutional efforts at making Mercosur's institutions stronger, including those promoting trade facilitation. ${ }^{4}$ To this end, the document anticipated the implementation of the trade facilitation measures depicted in the "Action Plan" agreed at the Madrid Summit in 2002. Capacity building also included informational mechanisms through technical training and administrative knowhow, as in the case of European Technical Assistance aimed at training Mercosur customs officials and through missions by EU experts to the Southern customs administrations.

This trend continued in the 2007-2013 RSP, which identifies three main challenges: support of regional integration, preparation of the implementation of the future trade chapter of the association agreement, and trade-related assistance. With a focus on trade policy and regulation, the report now specifies the content and type of regulatory norms to be promoted in the area of trade facilitation. In this respect, it highlights the acceptance of international standards, namely, the World Customs Organization (WCO) Framework of Standards to Secure and Facilitate Global Trade. ${ }^{5}$ Furthermore, the objectives of trade related assistance mechanisms will be dealt with at the regional level and cooperation will rely on a clear and strategic action plan based on Mercosur's own integration work programme.

Assistance in the area envisages financial, informational and organizational mechanisms to promote capacity building and the improvement of trade and customs procedures. Once again, the high level of financial assistance reflects the priority given to Mercosur's efforts for the completion of the common market, which receives $70 \%$ of the $€ 50$ million allocated. Moreover, part of the money assigned for the 2002-2006 period that had not been spent was re-directed towards further trade-related technical assistance, especially on customs (EC 2007). Informational assistance is also relevant as

\footnotetext{
${ }^{4}$ The other two areas of the cooperative strategy were intended to make the bloc's economic and trade structures more dynamic and integrated and to support civil society (44\% and $30 \%$ of total funding, respectively).

${ }^{5}$ Since 1994, WCO gives voice to 180 customs administrations across the globe, and provides leadership, guidance and support to customs administrations to secure and facilitate trade, protect society and build capacity, among other objectives. For further details, see http://www.wcoomd.org/en.aspx, last accessed 21 April 2016.
} 
both parties emphasize the importance of technical cooperation to promote trade facilitation, as in the case of the Mercosur-EU Customs Cooperation Project (PADUEM). Led by the private sector, PADUEM was to provide an adequate response to regulatory harmonization through the simplification and harmonization of norms related to customs procedures, information technology support, correct application of the common customs tariff, adoption of an agreement for mutual backing between Mercosur member states, modernization of human resources management, and customs training. ${ }^{6}$ Finally, emphasis was put on the use of European Technical Assistance, despite the "plenty of qualified local experts available" (Team 2006, 14).

Trade facilitation was also included in the agenda of the EU-Mercosur Biregional Negotiations Committee (BNC), the main negotiating body between the EU and Mercosur, including Council members, members of the EC's General Directorates for Trade and Foreign Affairs, and the foreign ministers of Mercosur countries. With the relaunch of trade negotiations in 2010, the issue of trade facilitation gained space in the agenda of the BNC. During the seventeenth meeting of the BNC (Buenos Aires, 2010), negotiators identified trade facilitation as one of the most important requirements achieved by 2004. In August 2010, Mercosur agreed to the Common Customs Code, which was then to be incorporated into national customs laws to assure implementation. $^{7}$ Clearly, both Mercosur governments and businesses had acknowledged that the relaunch of the interregional negotiation process would be meaningless without a joint customs code. These developments led to further progress in the interregional arena in terms of customs (trade facilitation) and related matters since both the EU and Mercosur clarified positions and exchanged proposals on customs and trade facilitation in October 2012 (BNC 2012). One year later, during the EU-Mercosur Ministerial Meeting, held in parallel with the EU-CELAC Summit in Santiago, the Southern bloc did emphasize the importance of capacity building on customs cooperation whereas the EU agreed to define its position and provide information on this issue before the next round of negotiations. Both parties reaffirmed

\footnotetext{
${ }^{6}$ Available at http://arcaconsortium.weebly.com/paduem.html,, last accessed 20 April 2016.

${ }^{7}$ See “"Fantastic summit" effectively turns Mercosur into a customs union', available at http://en.mercopress.com/2010/08/04/fantastic-summit-effectively-turns-mercosur-into-acustoms-union, last accessed 20 April 2016.
} 
their commitment to advance negotiations to reach an agreement. However, the more concrete institutional recommendations - especially, the establishment of an EUMercosur Joint Customs Cooperation Committee, already established in the Buenos Aires Statement on Business Facilitation - are still lagging behind. ${ }^{8}$

\section{The actors, their roles and networks}

Through EU cooperation in trade facilitation, businesses supporting the agreement and relying on technical expertise in this area were granted direct access to the policymaking process. The Mercosur-EU Business Forum (MEBF) became hence involved in supporting trade facilitation. Created in November 1997, before the official launch of interregional trade negotiations, the MEBF aspired to offer an institutional framework for contributing to the consolidation of trade and inter-business relations. Even if trade facilitation was initially not on its agenda, a special group was established to deal with it. This was a rather "pragmatic" decision: "as interregional negotiations are not advancing, trade facilitation appears as an area where we can contribute positively to the interregional relation (...) and supposedly it benefits both parties."9

Already in 2001, the MEBF presented a very complete and ambitious set of actions to assist Mercosur-EU business on the basis that trade facilitation measures should address both restrictions to intra-Mercosur and inter-regional trade flows. These focused on three main areas: customs and customs procedures; standards, technical regulations and conformity assessment procedures; and electronic commerce (MEBF 2001). The Buenos Aires Statement on Business Facilitation "pursued a stepwise approach and formulated altogether 30 recommendations for short-, medium- and longterm actions" (MEBF 2003, 12), which were to be realized by governments though some of these "were supposed to be implemented by the business sector itself" (Peña 2008, 93). This document was the result of the close collaboration between the business and technical sectors, as in the case of Siemens and the Argentine Institute of

\footnotetext{
${ }^{8}$ The document states that only six articles are currently without brackets, one of these being 'the article on Special Committee on Customs, Trade Facilitation and Rules of Origin'.

${ }^{9}$ Interview with MEBF executive, Buenos Aires, 21 November 2007.
} 
Standardization and Certification (IRAM). ${ }^{10}$ Most of MEBF's recommendations found their way into the Business Facilitation Action Plan negotiated in 2002 and aimed at promoting Mercosur economic integration in the area of customs (EC 2002b). Furthermore, trade facilitation was also part of the EU's financial and technical assistance, and clearly aimed at backing up business objectives. As argued by the then Commissioner for External Relations, Chris Patten, EU cooperation policy instruments would encourage MEBF priorities (Patten 2002). Later on, the MEBF welcomed the cooperative initiatives decided in 2004, as these contributed to the integration of customs legislation within Mercosur, the training of personnel, improvement of computerized customs formalities, administrative co-operation and the fight against fraud. ${ }^{11}$ In 2006, the MEBF Plenary reiterates the economic importance of trade facilitation and proposes a short list of priorities.

Apart from its access to the negotiation process and the design and implementation of EU cooperation in trade facilitation, the MEBF managed to develop strong liaisons with other regional and extra-regional institutions. First, it developed close relations with Sciences Po as it commissioned the Chaire Mercosur at this university, a research project on fundamental issues affecting negotiations between the EU and Mercosur. ${ }^{12}$ Funded by the Inter-American Development Bank (IDB), as well as by companies and organizations in Argentina, Brazil and the EU, the project aimed at producing new ideas that would serve as the basis for developing common positions among the EU and Mercosur business communities and an action plan to deepen and strengthen inter-regional economic relations. In all, the objective was to elaborate a shared stance for influencing governmental agendas, being one of the four issues under examination "the crucial issue of Business and Trade Facilitation," which gave way to the launch of an 8-year project financed by the IDB. ${ }^{13}$ Additionally, the main insights were then discussed in two workshops (Buenos Aires and São Paulo, September 2007) and fuelled the MEBF's VII Plenary Conference (Lisbon, October 2007). One of the

\footnotetext{
${ }^{10}$ Interview with IRAM executive, Buenos Aires, 23 November 2007.

${ }^{11}$ Interview with MEBF executive, Buenos Aires, 21 November 2007.

${ }^{12}$ Interview with IRAM executive, Buenos Aires, 23 November 2007.

13 See http://www.iadb.org/en/projects/project-description-title,1303.html?id=RG-T1282, last accessed 20 April 2016.
} 
conclusions reached then was that "the business facilitation measures analyzed can be implemented outside the scope of the Association Agreement” (MEBF 2007, 4).

Whereas in terms of results, Lisbon failed to produce as substantive outputs as those derived from the Buenos Aires Declaration, for the first time the two main European bodies for Standardization were part of the meeting. These refer to the European Committee for Standardization (CEN) and the European Committee for Electro technical Standardization CENELEC), which constitute the joint European Standards Institution, together with the European Telecommunications Standards Institute (ETSI). Thus, the MEBF attempted further negotiations within the private sector, even if from a state perspective negotiations were already held back. However, the underlying goal was no longer the harmonization of norms between the EU and Mercosur, but rather the exchange of information and expertise among regulatory bodies. ${ }^{14}$

Public officials in Mercosur perceived capacity-building strategies in the areas of customs and trade facilitation as promoting more flow between national coordinators involved in projects, this being especially marked in the case of technical cadres (CCIMercosur 2012). Mercosur relies today on the joint management of voluntary regional normalization and standardization through the Mercosur Association of Normalization $(\mathrm{AMN})$. Recognized by the Common Market Group (CMG), ${ }^{15}$ AMN replaced the old Mercosur Committee of Normalization in 1999 and since then, has been the only organization responsible for the development of Mercosur Norms (NM). ${ }^{16}$ In doing so, the AMN gives priority to international norms over regional norms and those established within Mercosur member countries. In all, AMN preferences are for international norms, namely those promoted by the International Organization for Standardization (ISO), the International Electro Technical Commission (IEC) and the

\footnotetext{
${ }^{14}$ Interview with IRAM executive, Buenos Aires, 23 November 2007.

${ }^{15}$ The CMG is the executive branch of Mercosur, made up of the Ministers of Foreign Affairs and of Economy, and Central Banks' presidents, plus permanent coordinators from each member country.

${ }^{16} \mathrm{AMN}$ is a private non-profit and non-governmental organization, composed by the four national institutions of standardization and certification. For further details, see http://www.amn.org.br/,last accessed 21 April 2016.
} 
International Telecommunication Union (ITU). From a regional perspective, norms elaborated by the Pan American Standards Commission (COPANT) also precede EU norms, as in the cases of CENELEC or CEN.

While demanding active and innovative participation from the private sector, the MEBF also stresses the importance of international standards supporting trade facilitation - namely, WCO - and highlights the continuation and enhancement of cooperation projects, including training programs and technical assistance plans, between the EU and Mercosur (MEBF 2001). Similarly, Mercosur negotiators emphasize "the importance of capacity-building on customs cooperation" when dealing with the trade agenda (BNC 2012, 6).

Finally, during the inter-regional process, the EU has mainly promoted the elaboration of Mercosur norms based on international standards, which contrasts with later agreements such as those with Chile and Mexico that go even further and include the creation of a Special Committee on Customs Cooperation (Fasan 2004; Maur 2005). In the case of the EU-Mercosur process, even if this is part of the negotiation agreement, the implementation of such a committee is still awaiting. ${ }^{17}$

\section{Education within the EU-Mercosur process}

\section{Norms and capacity-building mechanisms}

Education is also part of the free trade agenda between the EU and Mercosur, under trade liberalization in services, including commitments in the area of higher education (HE) and a whole range of knowledge intensive services (ÖFSE 2009). As such, educational matters are negotiated within the BNC. Still, liberalization of educational services has not been a relevant issue in the inter-regional negotiation process and has mainly advanced through the cooperative agenda. Furthermore, under the trade agenda,

\footnotetext{
${ }^{17}$ Another relevant international norm in the area is the WTO Trade Facilitation Agreement (TFA) passed in 2013. The agreement sets out measures to eliminate non-tariff barriers and to promote more efficient customs procedures. It also supports cooperation between customs and other appropriate authorities on trade facilitation, and contains provisions for technical assistance and capacity building. So far, Brazil and Paraguay are the only Mercosur member that have ratified the TFA.
} 
liberalization in the education sector has worked as a "bargaining chip" for the negotiation of other issues in which Mercosur countries have opposing interests, as in the case of agriculture (Botto and Peixoto 2009). Additionally, interregional negotiations in this policy area forced Mercosur members to agree on a common position towards trade liberalization in services, including education. In turn, this led to the signing of the Protocol of Montevideo on Trade in Services in 1997, which entered into force in 2005 and would bring about a complete liberalization of intra-regional trade in services by December 2015.

EU-Mercosur cooperation in education strongly supports civil society, namely academics, social and economic partners, and non-governmental organizations (NGOs). Relevant financial, informational and organizational mechanisms are part of the capacity-building strategy of the EU (RSP 2002-2006). Apart from the financial assistance instruments and projects related to the provision of information about negotiations and their impact on both regions, cooperation in the field of education is set to contribute to legislative harmonization and the development of common policies in Mercosur, while also supporting educational programs in vulnerable sectors. Capacitybuilding mechanisms also include informational resources through European technical assistance in those areas where EU proficiency is relevant: advice on policy and legislative measures, training, workshops, dialogue and exchanges of expertise amongst relevant agents in both regions, together with the development of specific Mercosur measures.

These objectives are still valid under the 2007-2013 RSP, which promotes both informational and organizational mechanisms through the strengthening and enhancing of civil society participation, knowledge of the regional integration process, mutual understanding and mutual visibility. To this end, cooperation focuses on the creation of EU-Mercosur study centres, ${ }^{18}$ the organization of workshops and seminars to promote the interchange of expertise and assistance, together with support of the "Plan of the Mercosur Educational Sector 2006-2010.” Twenty per cent of the $€ 50$ million allocated

\footnotetext{
${ }^{18}$ Building on the new Development Cooperation Instrument, the European Parliament called on the Commission to withdraw this initiative, in particular the creation of European/Mercosur documentation centres, EU and Mercosur Study Chairs, and Masters' degrees in EU and Mercosur Studies, as this would only widen the gap between rich and poor (EP 2007).
} 
for the period is directed toward this, while $€ 10$ million is assigned to two projects in the area of education and information that were not finalized under the previous RSP. Projects and programs financed under the CSP and various Latin American regional programs complement these resources. This cooperative strategy relies heavily on Mercosur's new cooperative agenda, which includes, among other issues, the mutual recognition of diplomas. Only in 2011 did EU cooperation in education reach higher levels by contributing to two projects in this area.

First, the 2007 Annual Action Plan introduces the "Higher Education Mobility Support Program" (€3 million), which is based on the idea that intra-regional relations demand new steps in the integration process by elaborating regional policies in areas such as education, social cohesion and environment. The objective is to support the consolidation and expansion of Mercosur's own mobility program for undergraduates. In turn, this should contribute to establishing Mercosur citizenship and a sense of regional belonging among university students in the four member countries. Second, the "Support Program for the Mercosur Educational Sector" (PASEM) (€6,8 million), which was part of previous EU cooperative strategies, had to be reformulated and refocused on improving teacher instruction after the European Parliament refused to endorse it because it did not contribute to reducing poverty and hence could not be classified as development assistance. Co-financed by the EU and Mercosur, PASEM builds on informational assistance: apart from promoting initial and continuous teacher training, it focuses on policy design and management to enhance educational quality in the region, thus contributing to social cohesion and integration. Teacher training institutes in the region are the direct beneficiaries, and implementation relies on the national education ministries in each country.

Although the specific norms to be promoted are not explicitly acknowledged in the corresponding documents, in the area of education the EU cooperative agenda aims to generate common regulatory criteria for accreditation and the recognition of certificates. Whereas this is expected to facilitate the mobility of students and highlyskilled workers between the two regions, the strategy heavily relies, in more practical terms, on Mercosur's own regional process of regulatory harmonization in the area of education. 


\section{The actors, their roles and networks}

Interregional cooperation in the area of education is channelled through the Ministers of Education in Mercosur. Considered as a fundamental factor all four-member countries signed an integration protocol as early as 1991 to create the Meeting of Mercosur Education Ministers (RME), which would propose to the Common Market Council (CMC) measures aimed at coordinating the educational policies of the member states. ${ }^{19}$

Set up as an intergovernmental body, the RME "holds the decisive say in all matters concerning education" (Gomes, Robertson et al. 2012, 228). Its main objective is to promote training in human resources and to enhance the development and harmonization of educational systems, all of which are expected to improve students' and professionals' mobility and citizens' awareness of the integration process (Verger and Hermo 2010). Thus, the agenda of the RME revolves around three main areas: basic, technological and higher education. Additionally, this specialized meeting established a regional space called the Educational Sector of Mercosur (SEM) to encourage cooperation between member countries and with other regional blocs, strengthen relations between the SEM and other decision-making bodies, and develop a regional identity through mutual understanding as well as a culture of integration. ${ }^{20}$ Nevertheless, cooperation in the area of HE is not only about regional identity, but also about promoting regional and global competitiveness and engaging in a knowledgebased economy (Fulquet 2005). Within the SEM, the area of HE has advanced most, especially in terms of three thematic blocs: mobility, accreditation and legibility of degrees, and institutional cooperation. ${ }^{21}$

The preferences of the RME lie in the promotion of cooperation among member countries to endorse the harmonization of educational systems and build regional compatibilities (Gomes, Robertson et al. 2012) as well as competitiveness. In fact, the

19 In 1995, the RME was incorporated into Mercosur's institutional structure, though the Ministers of Education were not granted veto power over the bloc's formal decisions.

${ }^{20}$ Bolivia and Chile are fully-fledged members of the SEM.

${ }^{21}$ Regional regulatory developments in the area of HE in Mercosur include the Experimental Mechanism of Accreditation (MEXA) and the University Degree Accreditation System (ARCU-SUR), which also includes Bolivia and Chile into a permanent and binding regional mechanism. For further details, see Botto (2016). 
Plan for Mercosur's Educational Sector, established in 2006-2010, validated in 20112015, and which the EU supported, defines this sector as "an instance of political coordination to integrate education to the necessary social, economic and political processes for the development of the people and national societies. It designs and executes policies to promote an education of quality for all, contributing thus to Mercosur's objectives" (Mercosur 2005, 9).

Interregional cooperation is intended to enhance this regional strategy. To this end, EU cooperation has lately become more focused on mobility through a project called "Higher Education Mobility Support Program." Given the limited impact of the Mercosur Regional Academic Mobility of Accredited Careers (MARCA) and the limited financial resources, ${ }^{22}$ EU's cooperation in this particular policy field can be read as an attempt to base its strategies on Mercosur's particular objectives and needs. EU cooperation can certainly provide financial, informational and organizational resources through its own intra-regional experience in the area of HE, namely, the Erasmus Mundus and the Bologna Process.

Whereas cooperation is the objective guiding RME strategy, the trade liberalization agenda, which is led by the four Foreign Trade Ministries within the Mercosur technical committee on trade in services, relies on the idea that education is a commodity that can be provided by the market (Botto and Peixoto 2009). Though based on a different understanding of education - public vs. market good - trade liberalization in this area also involves the harmonization of standards, certificates and accreditation.

From the perspective of the EU, cooperation with Mercosur is certainly part of its "more explicit 'extra-regional' globalizing strategy" in the area of HE since the EC acknowledged the declining expansion of the services sector in Europe (Robertson 2010, 29). Starting in 2003 and with an increased impetus in 2008, HE has been part of the EU's drive to advance its economic position and influence in the world. To this end, several strategies were deployed, namely the Erasmus Mundus program, the General Agreement on Trade in Services (GATS) negotiations, together with EU external

\footnotetext{
${ }^{22}$ In 2004, the CMC established the Educative Sector Financing Fund (FEM) to finance education policies and programs for regional integration. Member states' annual contribution is US\$ 30,000, plus US\$ 2200 per million inhabitants aged between five and 24 years old (Mercosur 2011). Venezuela joined the FEM in 2015.
} 
relations directed towards the European Neighbourhood Policy, industrialized nations and developing countries as well (EC 2006). Furthermore, the Bologna Follow up Group has elaborated a common strategy for developing the external dimension of the European Higher Education Area (Zgaga 2006). This strategy clearly prioritized identifying partner regions - rather than countries - and intensifying the exchange of ideas and experiences, as in the case of Mercosur. All of this was expected to create the conditions for international mobility, recognition, cooperation and attractiveness (Robertson 2010).

Civil society has become more strongly involved in the cooperative agenda on education both at Mercosur level and within the interregional negotiation process. On the contrary, they have remained rather detached from the negotiation of services liberalization in general, and education in particular.

At the interregional level, the EU cooperative agenda in education provides room for collaborative strategies among institutions, agreements between the ministries of education, and the creation and strengthening of networks, as in the case of the IberoAmerican Summit of Rectors of Public Universities.

Even if the SEM does not envisage any institutional mechanism for the participation of civil society, this became apparent in 2006, when the First Mercosur Educational Forum (FEM) was organized, building on the initiative of civil society organizations (CSOs) under the Mesa de Organizaciones Solidarias con la Educación. Furthermore, the Mercosur Educational Platform (PEM) brought together social and educational organizations in Argentina, Brazil, Bolivia, Chile, Paraguay and Uruguay to promote access, equity and educational standards. Another relevant space is the Montevideo Group University Association (AUGM). Created in 1991, this network brings together public and autonomous universities in Argentina, Bolivia, Brazil, Chile, Paraguay and Uruguay to promote regional integration through scientific, technological, cultural and educational cooperation among members. In a similar vein, the 'Grupo Interuniversitario ARCAM, Universidades por y para el MERCOSUR', created in 1995, involves over 32 universities ( $82 \%$ are private universities).

These emerging networks comprise a wide spectrum of actors, ranging from professors and universities to CSOs. Organizations range from the more focused Ação Educativa, Instituto Paulo Freire and Fundación SES in Brazil and Argentina, respectively, to Asociación Conciencia and Poder Ciudadano in Argentina and 
Associação Brasileira de Organizações não Governamentais (ABONG) in Brazil. Trade unions, NGOs and social movements working in the area of education have thus become increasingly involved in these forums that aim to promote dialogue between state and civil society in the identification and elaboration of regional challenges (Verger and Hermo 2010).

In all, cooperation in education has activated a wide array of societal actors, on the one hand, and has enabled the establishment of close links with public officials on the other. This turns out to be especially evident in the project "Higher Education Mobility Support Program," which promoted relations between universities and students from the four member countries, leading to the establishment of various educational consortiums (CCI-Mercosur 2012). Thus, the particular programs promoted by the EU - the teacher mobility program and the project to support mobility in HE have in turn contributed not only to the construction of a Mercosur citizenship through greater mobility, but also to closer and more heterogeneous networks.

\section{Varying patterns of regional regulatory governance across policy areas}

Trade facilitation and education are part of the cooperative and trade agendas negotiated at the interregional level. However, they show different combinations of norms and capacity-building mechanisms. The institutional frameworks devised have led to particular strategic constellations and interactions, giving rise in turn to different regulatory governance regimes.

Trade facilitation constitutes a fundamental pillar in the process towards an association agreement. Despite the limited public information available through the records of BNC meetings in terms of the implementation of the Madrid Action Plan, the issue seems to have lost its cooperative dimension. It is now restricted to the main pillar of the interregional agreement: trade liberalization, and thus remains almost exclusively on the agenda of the BNC. On the contrary, though included in both the trade and cooperative agendas, the initiatives in the area of education show different objectives and barely interact. Furthermore, progress in education was more marked within cooperation with Mercosur, as shown by the more precise terms of the successive EU strategies. 
In respect of the nature of the norms promoted in trade facilitation, both the cooperative and trade agendas were led by a general agreement on the establishment of an international norm for encouraging trade among Mercosur countries and between those and the EU. Whereas initially, EU strategies supported Mercosur regulatory institutions, later emphasis is placed on the implementation of international standards and rules, i.e. WCO. This seems to be reflecting the preferences of Mercosur, including business and normalization institutions under the AMN. Whereas the promotion of international norms is one of the objectives of the Buenos Aires Action Plan, the AMN establishes that when elaborating $\mathrm{MN}$, international rules should be prioritized over domestic-regional ones, as in the case of the Ibero-American norm COPANT, and extraregional ones such as those coming from European institutions, namely CENELEC and CEN.

Within the field of education, the main norm promoted has been domesticregional. EU's cooperative strategies in education, aimed at promoting the exchange of expertise, technical knowledge and good practice between the blocs, are based on Mercosur's embryonic regional space. As a whole, Mercosur has developed intense coordination in the area of education since 1991. Starting with the integration protocol signed then by the Ministers of Education of the four member countries, education has been increasingly framed as a regional regulatory regime. It is thus one of the longeststanding attempts at framing policies at the regional level and one of the prime efforts at promoting common regional norms and standards in non-economic issues, together with health (Bianculli and Ribeiro Hoffmann 2016).

Despite significant differences in terms of the financial resources available for trade facilitation and education, the capacity-building mechanisms envisaged to promote both issues also employ informational and organizational tools. However, the number and types of actors addressed by these are the main difference. Mechanisms in the area of trade facilitation are directed at businesses and to a lesser extent, to normalization institutes, whereas the education agenda has allowed for the participation of a wider set of actors. These include the four ministries of education, together with societal representatives ranging from universities to CSOs and social movements. Hence, the institutional setting of the agendas for trade facilitation and education has led to the involvement of different actors, whose roles and networks vary too. 
The institutional setting provided by the negotiation of trade facilitation - within both the BNC and the cooperative agenda - has established an actor constellation marked by close ties between state and business based on the interchange of technical information and expertise. Given that the negotiation of regulatory commitments in this area entails discussing norms and standards, this demands close cooperation between state actors and non-state ones with the required expertise, which state actors in developing countries usually lack (Bianculli forthcoming). Additionally, governments increasingly rely on non-state actors, as shown by the creation of AMN. Whereas technical non-state bodies have gained more influence in the formation of Mercosur's regulatory regime, there is still no comprehensive record of measures undertaken by the private sector under the MEBF. Certainly, this actor had a sound impact on interregional negotiations through several initiatives concerning trade facilitation through the elaboration of a common stance based on sound technical information. However, MEBF's influence on recent developments remains obscure.

Finally, the interregional negotiation process has promoted closer cooperation though in a lax manner -across institutions on both sides of the Atlantic as shown by the interchanges with regulatory institutions in the EU and other international financial institutions, i.e. the IDB. In all, the final objective is no longer to advance regulatory harmonization but rather to promote informational exchange about norms and standards the different parties support.

The institutional setting provided by the agenda for education has addressed larger and more heterogeneous constituencies, including state actors in the RME with universities, social and political organizations, specialized NGOs, and various stakeholders at domestic and regional levels. Being closely related to the provision of public services, education is based on complex ideas, and trade liberalization and regulatory commitments in this area have spurred a wider range of state and non-state actors. Still, my analysis shows that combined with the promotion of Mercosur's own domestic-regional norms, it has allowed networks to include a wider array of actors, including non-trade ministries, in all four-member countries. Furthermore, in terms of the cooperative requirement, capacity-building mechanisms in the area have extended Mercosur's regional networks across the domestic and regional levels. 


\section{Some final remarks}

This article has analysed how interregionalism can act as an instrument to support and promote regional regulatory governance beyond the EU, and in turn further encourage and strengthen regional regulatory cooperation in the Global South. By looking into the EU and Mercosur interregional process in two different sectors, it has shown that interregionalism taken as capacity building may impact already during negotiations, though differently across policy areas. The findings reveal how and to what extent the institutional setting provided by the negotiation of regulatory commitments in trade facilitation and education has built a particular context for the articulation of different regulatory governance regimes.

The analysis provides thus three main insights. First, it shows that based on its relatively high levels of regulatory expertise and coherence, the EU is capable of exercising a regulatory normative role by engaging in interregional dialogue. Second, whereas the EU relies on different instruments to build institutional and regulatory capacities, the paper highlights the significance of capacity-building mechanisms, which ranged from technical assistance, knowledge transfer and normative aspects, as incentives for regional actors to implement, adopt and even strengthen regional regulatory changes. Furthermore, negotiations between the EU and Mercosur reveal that these may become even more relevant when trade liberalization either comes to a halt or shows little progress because of conflicting interests. Finally, it is clear that the ways in which interregional trade negotiations can promote particular regulatory governance regimes, that is to say, 'regionalism through interregionalism', do not take place in a vacuum. In this, the EU's influence depends on the extent to which its capacity-building mechanisms are consistent with regional processes.

Several elements have hindered the EU's promotion of stronger regulatory governance in the area of trade facilitation, namely governmental discrepancies and competition about norms, showing that the EU is not the only game in town. On the contrary, in the case of education, the EU-Mercosur process has accompanied an existing process of regulatory governance through the RME and the SEM. Thus, the EU has strengthened this embryonic regional regulatory regime. With funding, but more importantly, through the interchange of expertise, experience and technical knowledge, the EU has provided Southern governments with valuable resources. In all, we can 
expect this cooperation to have an impact on the regulatory capabilities of Southern states and the consolidation of the regional arena as a new regulatory space.

The article also illustrates a broader point: the need to deepen our understanding of the ways in which regulatory governance advances in the Global South. Whereas the focus has been on the interregional negotiation process between industrialized and developing countries under the EU and Mercosur, future research should look into the impact of the increasing integration among countries and regional blocs in the developing world. This is a question of importance not only for Latin America, but also for the remainder of the Global South in a context marked by the limitations of interregionalism, the creation of new regional blocs and the emergence of regional powers that challenge the more normative (global and regional) governance scripts. 


\section{References}

Bianculli, A. C. forthcoming. Negotiating Trade Liberalization in Argentina and Chile: When Trade Policy Creates Domestic Politics. Abingdon and New York: Routledge

Bianculli, A. C. and A. Ribeiro Hoffmann. 2016. Regional Integration and Health Policies: Regulatory Governance Challenges in Mercosur. In Regional Organizations and Social Policy in Europe and Latin America. A Space for Social Citizenship?, edited by A. C. Bianculli and A. Ribeiro Hoffmann, 251-270. Basingstoke: Palgrave Macmillan.

Bianculli, A. C. 2013. The Brazilian Association of Regulatory Agencies: Integrating levels, consolidating identities in the regulatory state in the South. Regulation \& Governance 7.4: 547-559.

BNC. 2012. XXV Mercosur-European Union Birregional Negotiations Committee: Final Conclusions. Brasilia.

Börzel, T. A., Y. Pamuk and A. Stahn. 2008. The European Union and the Promotion of Good Governance in its Near Abroad. One Size Fits All? SFB-Governance Working Paper Series. Berlin, Freie Universität Berlin, Sonderforschungsbereich "Governance in Räumen begrenzter Staatlichkeit". 18.

Börzel, T. A. and T. Risse. 2007. Europeanization: The Domestic Impact of EU Politics. In Handbook of European Union Politics, edited by K. E. Jorgensen, M. A. Pollack and B. Rosamond, 483-504. London: Sage.

Botto, M. 2016. Policy diffusion and higher education reforms: Between market and state regulation - Where does Mercosur stand?. In Regional Organizations and Social Policy in Europe and Latin America. A Space for Social Citizenship?, edited by A. C. Bianculli and A. Ribeiro Hoffmann, 165-184. Basingstoke, Palgrave Macmillan.

Botto, M. 2009. The Role of Epistemic Communities in the Makability of MERCOSUR. In The EU and World Regionalism. The Makability of Regions in the 21 st Century, edited by P. De Lombaerde and M. Schulz, 171-185. Aldershot: Ashgate Publishing Ltd.

Botto, M. and J. Peixoto. 2009. The Impact of Academia on the Negotiations on Health and Education Services in Argentina: Challenges and Opportunities. In Research and International Trade Policy Negotiations. Knowledge and Power in Latin America, edited by M. Botto. London: Routledge - IDRC.

Briceño-Ruiz, J. and A. Puntigliano Rivarola. 2009. The European Union and the Making of South American Regionalism. In The EU and World Regionalism: The Makability of Regions in the 21st Century, edited by K. G. Deutsch and M. Schulz, 101114. Aldershot: Ashgate Publishing Ltd.

Bruszt, L. and G. A. McDermott. 2012. Integrating Rule Takers: Transnational Integration Regimes Shaping Institutional Change in Emerging Market Democracies. Review of International Political Economy 19.5: 742-778.

CCI-Mercosur. 2012. Evaluación de la cooperación técnica Mercosur-UE para el período 2000-2011 (Evaluation of Mercosur-EU technical cooperation during the period 2000-2011). Brasilia, Grupo de cooperación internacional del Mercosur.

Cohen, D. and M. Thatcher. 2008. Network Governance and Multi-level Delegation: European Networks of Regulatory Agencies. Journal of Public Policy 28.01: 49-71. 
Chauffour, J.-P. and J.-C. Maur. 2010. Beyond Market Access. The New Normal of Preferential Trade Agreements. Policy Research Working Paper Series. Washington DC, The World Bank. 5454.

Damro, C. 2012. Market power Europe. Journal of European Public Policy 19.5: 682699.

De Lombaerde, P. and M. Schulz, Eds. 2009. The EU and World Regionalism. The Makability of Regions in the 21st Century. Aldershot, Ashgate Publishing Ltd.

Djelic, M.-L. and K. Sahlin-Andersson, Eds. 2006. Transnational Governance. Institutional Dynamics of Regulation. Cambridge, Cambridge University Press.

Doctor, M. 2015. Interregionalism's impact on regional integration in developing countries: the case of Mercosur. Journal of European Public Policy 22.7: 967-984.

Doidge, M. 2007 Joined at the Hip: Regionalism and Interregionalism. Journal of European Integration 29.2: 229-248.Dri, C. F. 2010. Limits of the Institutional Mimesis of the European Union: The Case of the Mercosur Parliament. Latin American Policy 1.1: $52-74$.

Dubash, N. K. and B. Morgan. 2012. Understanding the rise of the regulatory state of the South. Regulation \& Governance 6.3: 261-281.

Duina, F. 2006. The Social Construction of Free Trade. The European Union, NAFTA, and Mercosur. Princeton and Oxford: Princeton University Press.

Eberlein, B. and E. Grande. 2005. Beyond delegation: transnational regulatory regimes and the EU regulatory state. Journal of European Public Policy 12.1: 89-112.

EC. 2002a. Mercosur-European Community, Regional Strategy Paper, 2002-2006. Brussels, European Commission.

EC. 2002b. Unión Europea-Mercosur: Una Asociación para el Futuro (European UnionMercosur: An Association for the Future). Montevideo, Comisión Europea.

EC. 2004. Trade Policy in the Prodi Commission, 1999-2004: An Assessment. Brussels, European Commission.

EC. 2006. Delivering on the Modernisation Agenda for Universities: Education, Research and Innovation. COM (2006) 208 final, 10 May. Brussels, European Commission.

EC. 2007. Unión Europea-Mercosur: El Desafío de una Integración Regional (European Union-Mercosur: The challenge of regional integration). Montevideo, Commission Delegation to Uruguay and Paraguay.

EP. 2007. European Parliament resolution of 7 June 2007 on the draft Commission decision establishing Regional Strategy Papers and Regional Indicative Programmes for Mercosur and Latin America. Brussels, European Parliament.

Faber, G. and J. Orbie. 2008. The new trade and development agenda of the European Union. Perspectives on European Politics and Society 9.2: 192-207.

Farrell, M. 2009. EU policy towards other regions: policy learning in the external promotion of regional integration. Journal of European Public Policy 16.8: 1165-1184.

Fasan, O. 2004. Comparing EU Free Trade Agreements: Trade Facilitation. ECDPM InBrief Maastricht, ECDPM. 6F. 
Featherstone, K. and C. Radaelli, Eds. 2003. The Politics of Europeanization. Oxford, Oxford University Press.

Fulquet, G. 2005. El Proyecto Educativo para el MERCOSUR y los Debates en torno a la Internacionalización de la Educación Superior. Buenos Aires: CAEI - Centro Argentino de Estudios Internacionales.

Gomes, A. M., S. L. Robertson and R. Dale. 2012. The social condition of higher education: globalisation and (beyond) regionalisation in Latin America. Globalisation, Societies and Education 10.2: 221-245.

Grugel, J. 2004. New Regionalism and Modes of Governance - Comparing US and EU Strategies in Latin America. European Journal of International Relations 10: 603-626.

Grugel, J. 2007. Democratization and Ideational Diffusion: Europe, Mercosur and Social Citizenship. Journal of Common Market Studies 45.1: 43-68.

Hameiri, S. and K. Jayasuriya. 2011. Regulatory Regionalism and the Dynamics of Territorial Politics: The Case of the Asia-Pacific Region. Political Studies 59: 20-37.

Hänggi, H. 2003. Regionalism through interregionalism: East Asia and ASEM. In Regionalism in East Asia: Paradigm Shifting?, edited by F. Liu and P. Régnier, 197219. London: RoutledgeCurzon.

Holman, O. 2004. Asymmetrical regulation and multidimensional governance in the European Union. 11.4: 714 - 735.

Jayasuriya, K. 2008. Regionalising the state: political topography of regulatory regionalism. Contemporary Politics 14.1: 21-35.

Jayasuriya, K. 2009. Regulatory regionalism in the Asia-Pacific: drivers, instruments and actors. Australian Journal of International Affairs 63.3: 335-347.

Jordana, J. and D. Levi-Faur, Eds. 2004. The Politics of Regulation. Cheltenhan, UK, Edward Elgar.

Knill, C. and A. Lenshow. 2004. Modes of Regulation in the Governance of the European Union: Towards a Comprehensive Evaluation. In The Politics of Regulation, edited by J. Jordana and D. Levi-Faur, 218-244. Cheltenham: Edward Elgar.

Lamy, P. 2002. Statement of Commissioner Lamy announcing successful end to negotiations on EU-Chile Association Agreement. IP/02/630.

La Nación. 2015. Acuerdan en el Mercosur negociar en conjunto con la Unión Europea, 18 July.

Lenz, T. 2012. Spurred Emulation: The EU and Regional Integration in Mercosur and SADC. West European Politics 35.1: 155-173.

Levi-Faur, D. and J. Jordana. 2005. The Rise of Regulatory Capitalism: The Global Diffusion of a New Order: The ANNALS of the American Academy of Political and Social Sciences, 598 (1).

Lipschutz, R. D. and C. Fogel. 2002. "Regulation for the rest of us?" Global civil society and the privatization of transnational regulation. In The Emergence of Private Authority in Global Governance, edited by R. B. Hall and T. J. Biersteker, 115-140. Cambridge: Cambridge University Press.

Lodge, M. 2008. Regulation, the Regulatory State, and European Politics. West European Politics 31.1-2: 280-301. 
Lowi, T. J. 1964. American Business, Public Policy, Case Studies and Political Theory. World Politics 16.4: 667-715.

Maihold, G. 2010. "La productividad del proceso de cumbres euro-latinoamericanas. Una evaluación a diez años de Rio". In Las Negociaciones entre América Latina y el Caribe con la Unión Europea, edited by G. Caetano, 21-60. Montevideo: Ediciones Trilce.

Majone, G. 1994. The rise of the regulatory state in Europe. West European Politics 17.3: 77 - 101 .

Mandelson, P. 2005. Open markets, open trade: Europe's global challenge. Speech given at the Market Access Symposium, European Parliament.

Maur, J.-C. 2005. Exporting Europe's Trade Policy. The World Economy 28.11: 15651590.

McGowan, F. and H. Wallace. 1996. Towards a European Regulatory State. Journal of European Public Policy 3.4: 560-576.

MEBF. 2001. Buenos Aires Statement on Business Facilitation. Buenos Aires, MEBF.

MEBF. 2007. Lisbon Declaration. Lisbon, MEBF.

Mercosur. 2005. Plan del Sector Educativo del Mercosur 2006-2010 [Plan of the Mercosur Educational Sector 2006-2010]. Montevideo, Sector Educativo del Mercosur.

Mercosur. 2011. Decisión Nro. 6 Consejo Mercado Común 'Fondo de financiamiento del sector educativo del Mercosur' (Fund to finance the educational sector of Mercosur). Montevideo, Consejo Mercado Común (CMC).

ÖFSE. 2009. Internationalisation of Higher Education and Development. -. E. 15. Viena, Österreichische Forschungsstiftung für Internationale Entwicklung (ÖFSE). 15.

Patten, C. 2002. III Conference EU - Mercosur Business Forum, speech given at the Closing Session.

Peña, F. 2008. Mercosur-EU experience and proposals for a 2008-2009 MEBF Action Plan. In Reviving the EU-MERCOSUR Trade Talks, edited by A. G. A. Valladao and M. Marconini, 93-101. Rio de Janeiro: Sciences Po-Chaire Mercosur-Fecomercio.

Phillips, N. 2001. Regionalist governance in the new political economy of development: 'Relaunching' the Mercosur. Third World Quarterly 22.4: 565-583.

Robertson, S. L. 2010. The EU, 'regulatory state regionalism' and new modes of higher education governance. Globalisation, Societies and Education 8.1: 23-37.

Ruggie, J. G. 1982. International Regimes, Transactions, and Change: Embedded Liberalism in the Postwar Economic Order. International Organization 36.2: 379-415.

Sanchez Bajo, C. 2005. European Union-Mercosur Interregionalism: Negotiations, Civil Society and Governance. In The Political Economy of Regions and Regionalism, edited by M. Bøås, M. H. Marchand and T. Shaw, 33-57. Basingstoke: Palgrave MacMillan.

Santander, S. 2005. The European Partnership with Mercosur: a Relationship Based on Strategic and Neo-liberal Principles. Journal of European Integration 27: 285-306.

Scharpf, F. W. 1999a. Governing in Europe: Effective and Democratic? Oxford: Oxford University Press. 
Scharpf, F. W. 1999b. Negative and Positive Integration in the Political Economy of European Welfare States. In Governance in the European Union, edited by G. Marks, M. Schulz, P. C. Schmitter and W. Streeck, 15-39. London: SAGE.

Söderbaum, F. and L. Van Langehove. 2005. Introduction: The EU as a Global Actor and the Role of Interregionalism. Journal of European Integration 27: 249-262.

Söderbaum, F. and A. Sbragia. 2010. EU Studies and the 'New Regionalism': What can be Gained from Dialogue? Journal of European Integration 32.6: 563-582.

Team, R. S. 2006. Sector Report: Trade and Regional Integration. Brussels, ROM Support Team.

Treib, O. 2008. Implementing and complying with EU governance outputs. Living Reviews in European Governance 3.5.

Van Loon, A. 2015. From Interregionalism to Bilateralism: Power and Interests in EUBrazil Trade Cooperation. In The European Union and the BRICS. Complex Relations in the Era of Global Governance, edited by Marek Rewizorski, 141-159. Dordrecht: Springer.

Verger, A. 2008. Measuring Educational Liberalisation. A Global Analysis of GATS. Globalisation, Societies and Education 6.1: 13-31.

Verger, A. and J. P. Hermo. 2010. The governance of higher education regionalisation: comparative analysis of the Bologna Process and MERCOSUR-Educativo. Globalisation, Societies and Education 8.1: 105 -120.

Wilson, J. Q., Ed. 1980. The Politics of Regulation. New York, Basic Books.

Woll, C. and A. Artigas. 2007. When trade liberalization turns into regulatory reform: The impact on business-government relations in international trade politics. Regulation and Governance 1.2: 121-138.

Young, A. R. and J. Peterson. 2006. The EU and the New Trade Politics. Journal of European Public Policy 13.6: 795-814.

Zgaga, P. 2006. Looking out: The Bologna Process in a Global Setting - on the External Dimension of the Bologna Process. Oslo, Norwegian Ministry of Education Research. 